\title{
Rain forests of central Borneo-threatened by modern development
}

\author{
Richard E. Bodmer, Robert J. Mather and David J. Chivers
}

Rain forests in Central Kalimantan, Borneo, are under increasing pressure from commercial industry, agricultural projects and transmigration programmes. Our knowledge of the hill forests in central Borneo is virtually non-existent, yet they may disappear before we realize their true value as intact forests. These rapid developments prompted the FFPS to launch the Red Alert Project, which, together with Project Barito Ulu, is investigating ways to promote rain-forest conservation in Kalimantan, Indonesia.

\section{Introduction}

Despite the tremendous importance of tropical rain forests we are continually faced with disheartening news about the high rate of forest destruction in all three major blocks: Africa, South America and South East Asia. Tropical forests in South East Asia occur on the mainland continent and in many islands of the Malay Archipelago. Most virgin forests in South East Asia have already been reduced to small pockets surrounded by vast stretches of heavily disturbed habitat. The largest remaining tracts of undisturbed rain forest occur on the islands of Borneo and Irian Jaya/Papua New Guinea (Whitmore, 1985). These islands differ greatly in fauna, with Irian Jaya having an Australian composition and Borneo a Malesian one.

The greatest expanse of undisturbed rain forest in Borneo lies at its centre. These forests differ markedly from those of the lowland coastal region, where most ecological studies have been conducted. The remoteness and inaccessibility of the central forests has until recently precluded major exploitation and development, which are now proceeding fast. Worse yet, the lack of biological studies in these forests makes us ignorant about a habitat that we may never know in its undisturbed form.

This paper describes the tropical forests of northern Kalimantan Tengah (Indonesia), central Borneo, and presents findings on mam- malian fauna found near the headwaters of the Barito river. We discuss how village Dayaks of this area use forest products and wildlife and how traditional patterns of land use are threatened by large timber, mining and petroleum operations, and increasing pressure from transmigration programmes. Solutions to conserve forests in Kalimantan will not be easy. The Barito Ulu Project consists of ecologists from a number of UK universities who are collaborating with Indonesian scientists to study forest regeneration, and, together with FFPS's Red Alert project, are specifically investigating potential solutions to ensure the survival of rain forests in central Borneo.

\section{Study area}

Wildlife and conservation surveys were conducted in tropical forests of the upper Barito watershed, otherwise known as Barito Ulu (Figure 1). The Barito river originates in hills within the province of Kalimantan Tengah, central Borneo. It is the widest river in Kalimantan and flows approximately $750 \mathrm{~km}$ (380 km straight distance) south to the South Java Sea. Study areas at Barito Ulu were located throughout the Joloi, Busang, and Murung tributaries. The study area had one principal base camp located on the Busang and four other minor camps.

Two major forests types occur in Borneo: (1) lowland forests, including swamps and man- 
groves, and (2) hill and montane forests. The latter occur at Barito Ulu. The terrain consists of undulating hills ranging from $150 \mathrm{~m}$ to 500 $\mathrm{m}$ above sea level, with many rocky outcrops, occasional cliff faces and fast-flowing streams. The forests vary widely, from areas dominated by emergent dipterocarps, to those dominated by smaller canopy species, to open areas of poor soil consisting of short vegetation. These poor soil areas are most frequent on hill-tops or slopes, which are prone to nutrient run-off and rapid drying.

Several Dayak villages occur at Barito Ulu. The largest consists of 52 households and is a conglomerate of two villages, Muara Joloi I and II, located at the confluence of the Murung and Joloi. Major activities of villagers include the collection of aloewood or gaharu, small-scale agriculture, fishing and hunting, along with assisting the timber company and aloewood operations with transportation of people and equipment.

\section{Mammal fauna}

Barito Ulu lies at the interface between the endemic fauna of Borneo and their immigrant counterparts from Sumatra. During the most recent Pleistocene glaciation many forestdwelling species became confined by a geographical barrier to refuges in northern and eastern Borneo. These refuges were formed by

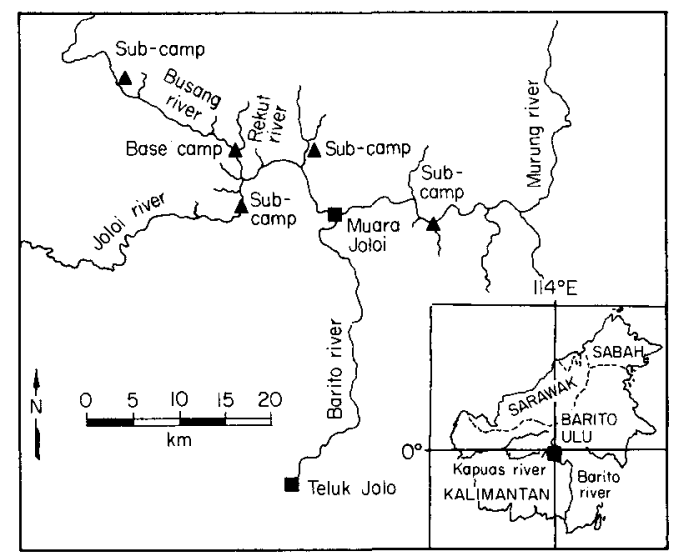

Figure 1. Map showing the location of the study area at Barito Ulu.

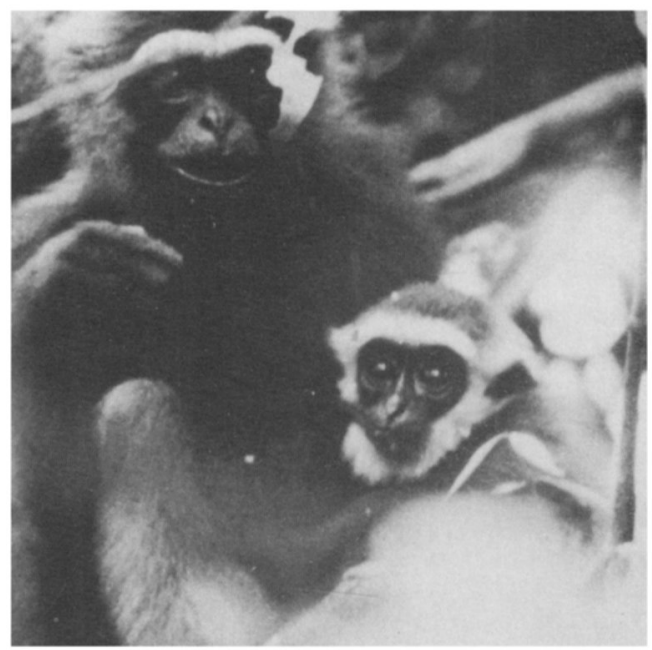

At Barito Ulu lies endemic Bornean fauna meet with the immigrant fauna of Sumatra. The best example of this faunal mixing is the hybridization between the Bornean gibbon and the agile gibbon. The latter species is shown above (Richard Bodmer).

the lowering of the tree line on the central mountain chain. The same glacial period connected Sumatra and Borneo by a land-bridge and enabled many 'mainland' species to invade south-western Borneo. When climatic conditions improved populations of both faunas expanded until they met the formidable barriers of the Barito and Kapuas rivers. The smaller headwaters of these rivers, such as Barito Ulu, enabled many species to cross the barriers and mix with related fauna.

Interactions between populations of Sumatran and Bornean fauna are still occurring at Barito Ulu. The best example is the mixing between Bornean gibbons Hylobates muelleri and agile gibbons $H$. agilis (Marshall and Sugardjito, 1986). The largest known zone of gibbon hybridization, covering an area of several thousand square kilometres, occurs at Barito Ulu. Gibbon calls are being used to study this hybridization. The great calls of females in particular are stereotyped and species-specific, and hybrids have a range of calls that reflect the degree of genetic mixing.

Viable gibbon hybrids of varying genetic mixtures are found between the Busang and Murung rivers at a density of 2.9 groups per sq $\mathrm{km}$ or 7.2 individuals per sq $\mathrm{km}$. Gibbon 
hybrids occur between the Busang and Joloi with $H$. agilis dominating the southern parts and $H$. muelleri the upper. Pure Bornean gibbons are found south-east of the Murung and pure agile gibbons south-west of the Joloi.

Borneo has many endemic fauna that do not have obvious Sumatran or Malay counterparts. One, the proboscis monkey Nasalis larvatus, is known from mangrove and swamp forests along the island's periphery (Bennett, 1986) and until recently was believed to occur only in coastal forests. Several groups have been sighted at Barito Ulu along the riverine forests of the Murung and upper Barito. They occur at much lower densities in hill forests than in coastal swamps and mangroves. For example, only one group of proboscis moneys was seen along a 4-km stretch of the Murung, whereas eight groups were sighted during an equivalent distance in swamp forests of the Sexonyer river, Tanjung Puting National Park, near the coast of southern Borneo.

Two species of langurs that are endemic to Borneo occur at Barito Ulu. The brightly coloured red langur Presbytis rubicunda is common along the Busang and Joloi and occurs at a density of 2.8 groups per sq $\mathrm{km}$ or 10.4 individuals per $\mathrm{sq} \mathrm{km}$. The darker white-fronted langur Presbytis frontata only occurs east of the Murung. Forests inhabited by white-fronted langurs have very low numbers of red langurs. This pattern of distribution at Barito Ulu may result from competition between these two ecologically similar species.

Orang-utans Pongo pygmaeus have been sighted at Barito Ulu, but occur at very low densities (less than 0.06 individuals per sq $\mathrm{km}$ ) with only two sightings during 14 months of field work. In contrast, nine wild orang-utans were seen in swamp forests of the Sexonyer river, Tanjung Puting National Park, during 8 days of field work. The different densities of orang-utans in swamp and hill forests are probably due to differences in abundance of fruiting trees, because orang-utans are largebodied frugivores that require a constant supply of fruit to maintain their energy requirements (Mackinnon, 1974; Galdikas, 1988).

Other primates seen at Barito Ulu include the long-tailed macaque Macaca fascicularis at

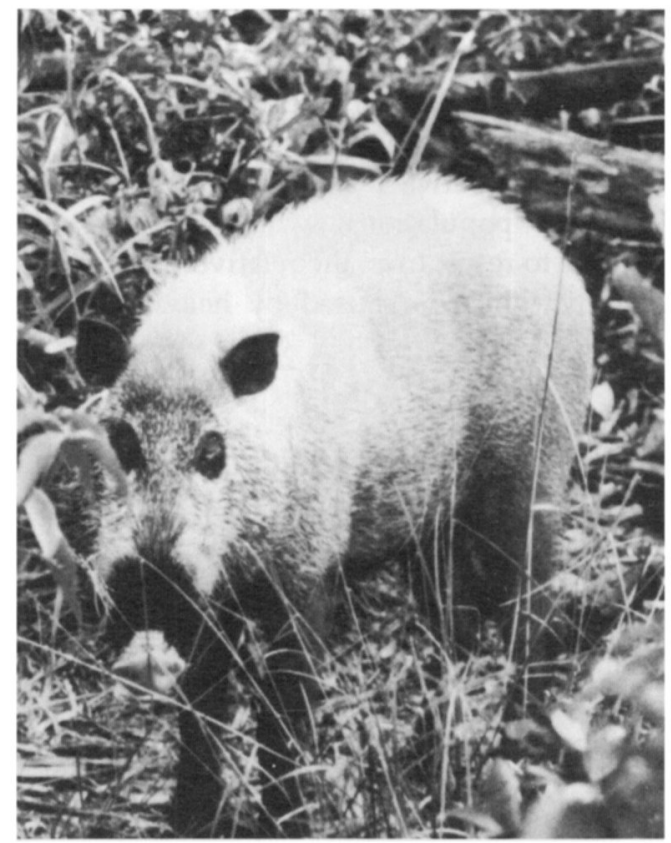

The bearded pig is the most abundant ungulate at Barito Ulu and is often seen in the riverine forests. They are important dispersal agents for rain forest fruits and play an essential role in forest regeneration. They are also important for subsistence hunters and a management programme is needed to avoid overexploitation (Richard Bodmer).

an overall density of 1.4 individuals per sq $\mathrm{km}$, the pig-tailed macaque Macaca nemestrina, which is not common in this area, and two nocturnal prosimians, the slow loris Nycticebus coucang and the western tarsier Tarsius bancanus.

Ungulates commonly sighted at Barito Ulu include the bearded pig Sus barbatus, Bornean yellow muntjac Muntiacus atherodes, common muntjac Muntiacus muntjac, sambar deer Cervus unicolor, lesser mouse deer Tragulus javanicus, and greater mouse deer Tragulus napu. Bearded pigs were the most common ungulate with a density of 1.2 individuals per $\mathrm{sq} \mathrm{km}$ followed by lesser mouse deer at 1.0 individuals per sq $\mathrm{km}$, greater mouse deer at 1.0 individuals per sq $\mathrm{km}$ and muntjacs at 0.9 individuals per sq $\mathrm{km}$. These forest ungulates consume large quantities of fruits and are probably major seed predators.

Barito Ulu is an important area to conserve 
because it has a high diversity of mammal fauna coupled with relatively low densities compared with other sites throughout South East Asia. The high diversity results from interactions between expanding Sumatran and Bornean populations, while low densities appear to result from the relatively scarce fruit supply, which is caused by heavily leached soils.

\section{Forest exploitation and conservation in central Borneo}

Conservation of tropical rain forests is difficult because they are complex environments with many interdependent resources. The following section will examine conservation in central Kalimantan with regard to indigenous subsistence and commercialized industry, both of which can be conducted either in a renewable or destructive manner.

Agriculture in Kalimantan is an example of how rain forests are used either in a renewable or non-renewable manner depending on the techniques employed (Kartawinata et al., 1984). Villagers at Barito Ulu, like those in many remote areas of Borneo, use a form of slash-and-burn agriculture that overall is not harmful to the rain forests (Kartawinata et al., 1984). Farmers rotate plots in level riverine areas instead of cutting virgin forests on steeper slopes and in turn do not harm large tracts of mature rain forest. In addition, multispecies gardens used by farmers at Barito Ulu increases the period of productivity. Damage to rain forests arises when the large commercial industries use slash-and-burn agriculture. Large agriculture programmes have heavy financial investment, which pressures them to clear virgin forest rather than wait the full length of time necessary for the recovery of previously cleared areas.

Game meat is another forest resource that is renewable if well managed, but can harm animal populations if over-exploited. For example, wild ungulates are an important source of game meat for people at Barito Ulu. Hunting deer and pigs for subsistence is renewable if the game is used by people living in remote villages (Caldecott, 1988). However, dried meat sold in markets of large towns might lead to over-hunting of ungulate populations. At present Kalimantan does not have any game management programmes and there is no monitoring of ungulates to determine their vulnerability to hunting.

Hunting is not the only activity harming animal populations. The live trade in primates and other animals is extensive throughout Indonesia and might be quite damaging to many species. Traders were seen selling orang-utans, siamangs, gibbons and macaques in markets in Kalimantan and Jakarta. In most cases animals were held in appalling conditions and no doubt many adults are needlessly sacrificed during the capture of infant primates, many of which die before reaching the markets.

Many minor forest products are used in a renewable manner by Dayaks for foods, medicines and building materials. Examples include timber of Eusideroxylon spp. (Bornean ironwood) and Shorea spp. for construction of houses and boat hulls, rattan Calamus spp. for weaving baskets and ropes, dammar resins for caulking boats, fruits, palm-hearts and fern tips for food, and edible birds' nests from cavedwelling swiftlets for export to China as a traditional medicine and a restaurant delicacy.

Aloewood, a fragrant heartwood, has been collected throughout Borneo for hundreds of years and appears to be a renewable resource that is re-collected after being left fallow for long periods. This minor forest product is currently being collected at Barito Ulu by villagers and transmigrants. It is used for Chinese medicines and as incense in Arabia and comes from trees of Aquilaria spp. (Thymelaceae) that have been diseased by fungal pathogens (Kartawinata et al., 1984; Jessup and Peluso, 1986). Aloewood is a valuable resource, which can fetch upwards of $£ 250$ per $\mathrm{kg}$ for the top grade. However, it is rapidly exhausted in an area, because only a small fraction of trees are infected. For example, in Barito Ulu aloewood collection only lasted a year in forests of the Joloi and Busang.

Development and conservation programmes can help managing minor forest 
products only if there is sufficient information available on the basic biology of the animal or plant being harvested. Studies in Borneo have investigated resources such as rattan and edible birds' nests (Jessup and Peluso, 1986). However, the basic biology of aloewood is lacking and more information is necessary to develop adequate management programmes.

Villagers extract gold in Kalimantan using both environmentally non-harmful and harmful techniques. For example, people of Muara Joloi pan for gold-dust in a large sand bar along the river bank and do not damage the environment. New sand is deposited and the supply of gold-dust is replenished every time the river rises. In contrast, settlers in the coastal swamp forests of Kalimantan have begun to use surface mining techniques that are severely damaging the rain forests.

Many commercial industries exploit forest resources in Indonesia and profits are normally channelled to large cities and not rural areas. Timber operations are the largest industries in Kalimantan, followed by petroleum and mining. Lumber companies can harm rain forests, because they often extract large quantitiies of living biomass.

Timber operations in Kalimantan use a form of selective logging. In practice this system damages up to 40 per cent of rain-forest habitats, while only removing 10 per cent of forest trees (Johns, 1983). Areas are then replanted with timber trees and left for 30 years to regenerate. Effects of selective logging on rain forests are poorly understood and depend on many factors including, (1) obedience of companies, (2) habitat type exploited, (3) natural regeneration time for timber species, and (4) animal vectors available for seed dispersal. Regeneration to mature forest, with the equivalent number of emergent trees as pre-logged forests, may take twice or three times as long as the proposed 30 years and the original diversity is probably never regained. Thus the second rotation of timber often consists of trees not felled during the first.

At Barito Ulu scientists are investigating how frugivorous animals that disperse seeds help regenerate selectively logged rain forests. It has already been shown that the relative

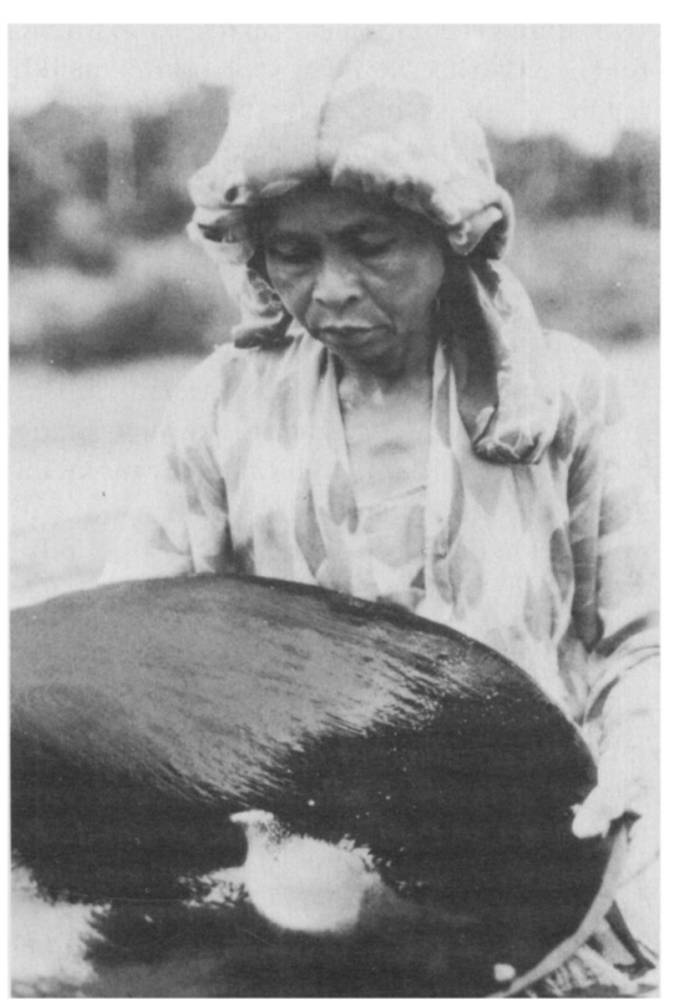

Dayaks of Muara Joloi pan gold in a sustainable manner, exploiting sand bars along the Barito river where new gold dust supplies are deposited during floods (Irvan Sidik)

abundance of frugivorous animals changes after an area has been selectively timbered (Johns, 1985). Taking this into consideration scientists are looking at the plant-animal interactions that occur in regenerating forests.

The timber industry in Kalimantan is very extensive and has moved from riverine extraction to more intensive inland operations. Expenditure on infrastructure is tremendous, because roads and bridges are continually being built. This necessitates the extraction of huge quantities of lumber in order to meet profit levels. For example, approximately 2-4 $\mathrm{km}$ of lumber roads are being built at Barito Ulu each week, and similar, if not more intensive, destruction is occurring throughout Kalimantan.

Timber industries in Kalimantan are heavily influenced and often directly sponsored by large Japanese companies. Indeed, one of the 
two lumber companies currently extracting timber at Barito Ulu is owned and operated by Japanese. Since 1985 raw timber cannot be exported from Indonesia and this regulation has slightly curtailed the rate of felling.

One of the more detrimentral effects of timber operations is the opening up of virgin forests for agriculture. This problem is greatly exacerbated by the influx of people into Kalimantan through the Indonesian transmigration programme. This programme, funded by the World Bank, relocates Javanese into areas of Kalimantan and results in dramatic population increases over short time periods.

Careful commercial exploitation of petroleum and mineral resources can bring great economic assistance to remote areas without necessarily doing much damage to rain forests. However, it is often the case that companies reduce costs by overlooking environmental concerns and in turn damage habitats. Prospecting for both petroleum and other minerals is occurring at Barito Ulu, but companies have yet to start major operations. Industries could set up very quickly at Barito Ulu, because of the infrastructure already made available by timber extraction.

Preservation of rain forests in Borneo is being aided by the conservation efforts of FFPS's Red Alert Project, which will help maintain existing protected areas and encourage Indonesians to set aside new ones. Protected areas should include both strict parks where most human activities are prohibited and reserves where local Dayaks can continue to utilize minor forest products and practice small-scale agriculture.

\section{Acknowledgments}

We would like to thank the Indonesian Ministry of Forestry and LIPI for permission to work at Barito Ulu and for their participation in the project. Special thanks are given to Dr Jito Sugardjito, Boeadi, Irvan Sidik, Sofian Iskandar, Roger Wilson, Rupert Ridgeway, Clare Hall, Lisa Thomas, Peter Brotherton, Helen O'Leary, Guy Dutson, Ben Sheldon and Roger Wilkinson for their assistance at Barito Ulu and at Cambridge. Survey work done by Richard Bodmer at Barito Ulu was sponsored by FFPS's Red Alert programme, and principal spon- sors of Project Barito Ulu include Wickes Europe plc., Hudbay Oil (Malacca Strait) Ltd, The Royal Geographical Society and Garuda Indonesia.

\section{References}

Bennett, E.L. 1986. Proboscis Monkeys in Sarawak: their Ecology, Status, Conservation and Management. WWF Project No. MAL 63/84, Kuala Lumpur.

Caldecott, J. 1988. Hunting and Wildlife Management in Sarawak. IUCN, Gland, Switzerland.

Galdikas, B.M.F. 1988. Orangutan diet, range, and activity at Tamnjung Puitng, cenral Borneo. Int. J. Primatol. 9, 1-35.

Jessup, T.C. and Peluso, N.L. 1986. Minor forest products as common property resources in East Kalimantan, Indonesia. In Proceedings of the Conference on Common Property Resource Management (eds. Panel on Common Property Resource Management), pp. 505-531. National Academy Press, Washington, D.C.

Johns, A.D. 1983. Ecological Effects of Selective Logging in a West Malaysian Rain-Forest. PhD thesis, University of Cambridge.

Johns, A.D. 1985. Selective logging and wildlife conservation in tropical rain-forest: problems and recommendations. Biological Conservation, 31, 355-375.

Kartawinatat, K. Soedjito, H., Jessup, T., Vayda, A.P. and Colfer, C.J.P. 1984. The impact of development on interactions between people and forests in East Kalimantan: a comparison of two areas of Kenyah Dayak settlement. The Environmentalist, 4, 87-95.

Mackinnon, J.R. 1974. The behaviour and ecology of wild orang-utans (Pongo pygmaeus). Anim. Behav. 22, 3-74.

Marshall, J.T. and Sugardjito, J. 1986. Gibbon systematics. In Comparative Primate Biology, Volume 1: Systematics, Evolution and anatomy (eds. D. R. Swindler and J. Erwin), pp. 137-185. Alan R. Liss, New York.

Whitmore, T.C. 1985. Tropical Rain Forests of the Far East. 2nd Edition. Clarendon, Oxford.

Richard E. Bodmer, Large Animal Research Group, Department of Zoology, 34A Storeys Way, Cambridge CB3 ODT and Dept. Zoologia, Museu Paraense Emilio Goeldi, Caixa Postal 399, 66.040 Belém, PA, Brazil.

Robert J. Mather, Sub-Department of Veterinary Anatomy, University of Campbridge, Tennis Court Road, Cambridge CB2 1QS, UK.

David J. Chivers, Sub-Department of Veterinary Anatomy, University of Cambridge, Tennis Court Road, Cambridge CB2 1QS, UK. 